Oryx

whole family, and deals only with his first love, the North Atlantic gannet. It is an excellent summary of what is known of its habits and ecology, much of it due to the author himself, and will be welcomed by many who are primarily interested in British or European birds and would find the majestic price of his larger book a deterrent.

Eric Simms's New Naturalist volume on British thrushes is squarely in the midtwentieth century tradition of summarising the voluminous information that now exists for some of the commonest birds in the British Isles. He deals fully with the six thrushes of the genus Turdus, on three of which he has himself done detailed field work, especially around his North London home. The lesser thrushes, such as chats, wheatears, robin and nightingale, are dismissed, not unreasonably, in a single chapter. This is the sort of book that ought to be written every twenty years or so for every major group of British birds. There are numerous excellent black and white photographs by Eric Hosking and others.

RICHARD FITTER

Wild Geese, by M.A. Ogilvie. T \& D Poyser, $£ 7.80$.

Another book from the talented and productive research team of the Wildfowl Trust. Malcolm Ogilvie, who has been with the Trust since 1960, follows his Ducks of Britain and Europe (1975) with an equally readable and competent companion volume. Here, in a text which has a similar layout to his book on ducks, he covers the geese of the world, apart from one species, the Hawaiian Goose, omitted on the grounds that it is in many ways an aberrant species and is the subject of a monograph which (we all hope) is about to be published. For a volume which rightly emphasises comparisons between species this was, I think, a mistaken decision. However, this is a minor quibble, for the book is an excellent compilation and précis of the vast amount of work that has been done. What is known about geese is here, in chapters on classification, identification, ecology, breeding, status, distribution, population dynamics, migrations, exploitation and conservation. Much of the work has been done in America and Europe, and where there are gaps in our knowledge it is mainly with Asian species. The text is supported by extremely good maps, easy-to-follow tables and index, line drawings, and 16 colour plates. I regret the omission of references in the text, for though there is a selected bibliography of some 200 references at the end, it is difficult and often impossible to check the information given.

There have been at least five other major works dealing with geese and other wildfowl in the last four years, but comparisons would be invidious and unfair for they are aimed at different audiences. Suffice to say if you have a sum approaching $£ 100$, buy the lot. If not, and geese are your particular interest, this volume is excellent value.

PETER OLNEY

\title{
The Art of Survival, by Colin Willock. Deutsch, $£ 6.50$.
}

Television, like the wild world outside, can be a savage habitat at times, red in tooth and claw. But thanks to the consistent excellence of Colin Willock's wildlife programmes, Anglia TV's Survival series has secured a permanent niche in the ratings pyramid, and earned over 30 awards in the process.

For nearly two decades Colin Willock has been scripting and producing Survival specials for TV. His first film focused on the wildlife of London. Since then he has worked on all kinds of creatures from geckos to humpback whales, and helped to make places such as Aldabra, Chitawan, Okavango and the Serengeti as familiar as the pavements of WC1. Now, with 300 films behind him, he has become Survival's chronicler. His book is basically the saga of a dedicated bunch of cameramen and women, and the extraordinary risks they take to bring the animal world to our TV screens. By virtue of 